\title{
Research on Developing Route of Brand Internationalization of OEM Enterprises
}

\author{
Yuhua Zhang ${ }^{1, a}$, Zhen Zhang ${ }^{1, b}$ \\ ${ }^{1}$ Guangdong University of Foreign Studies, Guangzhou 510000, China; \\ azhyh58@163.com, ${ }^{\text {b } 734503338 @ q q . c o m ~}$
}

Keywords: OEM enterprises, evolutionary path, brand internationalization.

\begin{abstract}
By analyzing relevant literature, this thesis constructed a theoretical model explaining how foundry enterprises evolved into an international brand by following the path of OEM-OEM-OBM-IBM. By dividing the market, this thesis presented 3 models and researched the strategies of 3 foundry enterprises that successfully achieved upgrading and brand internationalizing, aiming at provided some examples to other enterprises by exploring how different market entry models affect those own-built international brands.
\end{abstract}

\section{Introduction}

The research of Amsden (1989) indicates that in the emerging market, the best way for an OEM (Original Equipment Manufacture) enterprise to achieve its transformation and upgrading is to develop, design and ultimately build up its own brand from a simple OEM agent ${ }^{[1]}$. With the development of economic globalization, developed countries have been gradually got out of simple production and manufacturing, but rather focusing more on technology development and brand operation. Against this backdrop, OEM sprouts out rapidly. However, as time goes by, OEMs' disadvantages have been exposed gradually. In recent years, many OEM enterprises confronted some dilemmas while some of them achieved transformation and upgraded successfully. Some labor-intensive OEM manufacturers transformed into competitive ones of ODM (Original Design Manufacture) or OBM (Original Brand Manufacture) with proprietary technology and brand equity. Some even developed into IBM (International Brand Manufacture). Therefore, the operation trajectory for OEM enterprises' sustainable development and continuous high additional value shall be OEM-ODM-OBM-IBM, during which process, OEM enterprises can constantly enlarge and upgrade businesses. In consideration of saturated domestic industrial markets and driven by the value chain and huge profits, the advanced enterprises began to promote brand building by making use of the international market and also tried to achieve upgrading for local branches. From OBM to IBM, with the help of different market entry models, an OEM enterprise can learn advanced experience of marketing management and the knowledge of brand operation, promote its own brand building, develop its own products and turn technology to capital and eventually to the brand.

Analyzing previous researches, the author finds out that most of them discussed the issue of OEMs' transformation and upgrading, lacking of summary reports of upgrading strategies and methods at the OEM stage; they missed out OEMs' building up their own brands and choosing proper market entry models to develop the international brands. This essay will study the enterprises' upgrading route of OEM-ODM-OBM-IBM according to the core competence theory and global value chain theory. This essay will also study 3 successful enterprises who achieved brand internationalization by adopting different market entry models, hoping it can provide other OEM enterprises with reference on transformation and upgrading.

\section{Theory Model}

Core Competence and Global Value Chain. Both domestic and overseas researches on route of enterprises' transformation and upgrading originally started their discussion from a core competence 
angle and then inserted the global value chain theory for more reference. A genuine core competence is an enterprise's pivotal value-added activity. According to the core competence theory, Prahalad \& Hamel(1990) indicates that not all resources, knowledge and abilities can be transformed into enterprises' constant competitive advantages ${ }^{[2]}$. It emphasizes integration of various techniques and functions, and coordination among corresponding organizations. It is the source that keeps long term competitive advantages and obtains super profit for an enterprise.

In the framework of global value chain, enterprise upgrade is a dynamic process which obtains technique progress and market connection with the help of the value chain in order to improve additional value of both products and service accordingly. From the value chain angel, Humphrey \& Schmitz (2000) indicated that enterprises in developing countries were confronting with 4 types of upgrade models $^{[3]}$. OEM enterprises upgrade measures mainly consist of 2 aspects: 1) Control high additional value links in the global value chain such as technology research and development, and self-owned brand building up. 2) Enhance the governance ability of value chain.

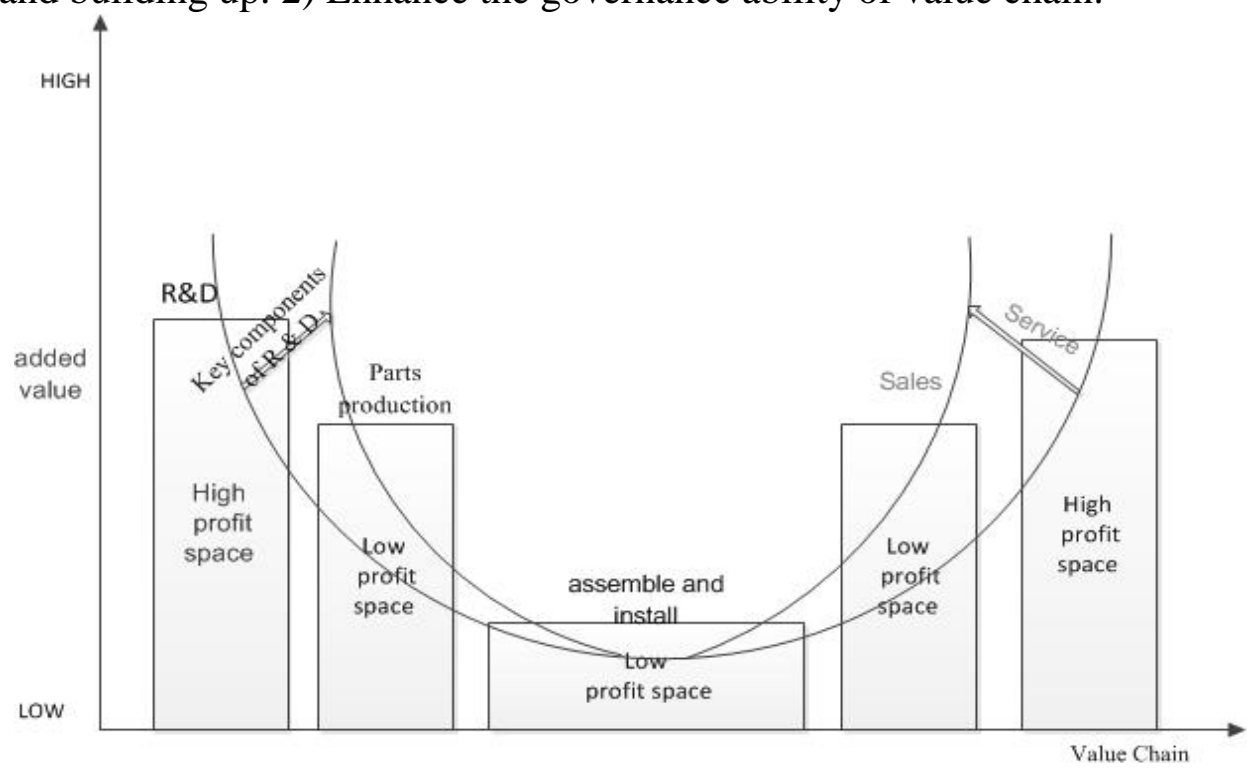

Fig. 1 Rising Model of Global Value Chain

Stage Comparative Analysis on OEM/ODM/OBM/IBM. On account of some scholars' studies, the core competence theory and the global value chain etc, table 1 comparatively analyzed the necessary core competence and development strategies for OEM enterprises' achieving functional upgrade.

Table 1 Stage Comparative Analysis on OEM/ODM/OBM/IBM 


\begin{tabular}{|c|c|c|c|c|}
\hline & \multicolumn{4}{|c|}{ Developing Route of OEM Brand Internationalization } \\
\hline Route & \multicolumn{4}{|c|}{$\mathrm{OEM} \longrightarrow \mathrm{ODM} \longrightarrow \mathrm{OBM} \longrightarrow \mathrm{OBM}$} \\
\hline Market Feature & $\begin{array}{l}\text { Cheap labor force } \\
\text { allocation; orders seriously } \\
\text { depending on suppliers; } \\
\text { quality cost base }\end{array}$ & $\begin{array}{l}\text { Superior products on } \\
\text { sale; } \\
\text { market-oriented product } \\
\text { design }\end{array}$ & $\begin{array}{l}\text { Self-owned brand on } \\
\text { sale;internal } \\
\text { marketing ability } \\
\text { improvement }\end{array}$ & $\begin{array}{l}\text { Self-owned brand } \\
\text { competing in } \\
\text { international } \\
\text { market }\end{array}$ \\
\hline Activity Form & $\begin{array}{l}\text { Standardized production } \\
\text { assembling; manufacturing; } \\
\text { adopting marketing of } \\
\text { brand card sticking on } \\
\text { goods }\end{array}$ & $\begin{array}{l}\text { Design and } \\
\text { manufacture, } \\
\text { technology innovation } \\
\text { and product design; } \\
\text { marketing of brand card } \\
\text { sticking on goods }\end{array}$ & $\begin{array}{l}\text { Competitiveness R\&D } \\
\text { capability; } \\
\text { product innovation; } \\
\text { self-owned brand } \\
\text { marketing }\end{array}$ & $\begin{array}{l}\text { Research and } \\
\text { development and } \\
\text { innovation ability; } \\
\text { build up brand } \\
\text { capital }\end{array}$ \\
\hline $\begin{array}{c}\text { Core } \\
\text { Competence }\end{array}$ & $\begin{array}{l}\text { Low cost, highly efficiently } \\
\text { manufacture capability }\end{array}$ & $\begin{array}{l}\text { Research, development } \\
\text { and design ability of } \\
\text { high quality products }\end{array}$ & $\begin{array}{l}\text { Self-owned brand } \\
\text { operation and } \\
\text { management }\end{array}$ & $\begin{array}{l}\text { Brand marketing, } \\
\text { international } \\
\text { operation ability }\end{array}$ \\
\hline $\begin{array}{l}\text { Development } \\
\text { Startegy }\end{array}$ & $\begin{array}{l}\text { Business range enlarging; } \\
\text { enhancing research and } \\
\text { development ability }\end{array}$ & $\begin{array}{l}\text { Enhancing design } \\
\text { ability; developing } \\
\text { self-owned brand }\end{array}$ & $\begin{array}{l}\text { Searching for brand } \\
\text { complementary } \\
\text { suppliers to maintain } \\
\text { competitive advantage }\end{array}$ & $\begin{array}{l}\text { Global market } \\
\text { purchase, business } \\
\text { stripping }\end{array}$ \\
\hline
\end{tabular}

Market Division during the Process of OEM Brand Internationalization. Achieving spanning from OBM to IBM is a progressive development procedure. When OEM enterprises carry out international businesses with their self-owned brands, they need to firstly consider and select target countries and areas; then evaluate both internal and external factors that would affect their entering the areas' markets; at last, by combining market's characteristics and companies' capabilities, comprehensively analyze what kinds of entrance model they should adopt. According to economy development degree, the current international market can be divided into 3 levels: 1) developed countries markets represented by North America, Europe and Japan. 2) medium developed countries markets represented by East Europe, South America and Asia Four Tigers etc. 3) underdeveloped countries markets represented by Vietnam, India and Africa etc.

On account of researches of scholars like Song Yonggao (2003) ${ }^{[4]}$, Su Yong (2003) ${ }^{[5]}$, and Wei Fuxiang $(2001)^{[6]}$,characteristics of the 3 levels markets are as the following table.

Table 2 Analysis on Advantage and Disadvantage Factors of Market Entrance

\begin{tabular}{c|c|c}
\hline Market Level & Advantage Factors & Disadvantage Factors \\
\hline $\begin{array}{c}\text { Developed } \\
\text { Countries }\end{array}$ & $\begin{array}{c}\text { Clear-cut regulation and standard, huge } \\
\text { market scale, mature consumption concept }\end{array}$ & $\begin{array}{c}\text { High entrance barrier, mature consumption } \\
\text { concept, high requirement of product quality }\end{array}$ \\
\hline $\begin{array}{c}\text { Medium } \\
\text { Coveloped }\end{array}$ & $\begin{array}{c}\text { Bigger market scale, normal customers } \\
\text { loyalty, medium quality standard }\end{array}$ & $\begin{array}{c}\text { Strong brand has a certain position but it has } \\
\text { hidden danger on long term development. }\end{array}$ \\
\hline $\begin{array}{c}\text { Underdevelope } \\
\text { d Countries }\end{array}$ & $\begin{array}{c}\text { Low entrance barrier, little competitive } \\
\text { market, easily attaining quality standard }\end{array}$ & $\begin{array}{c}\text { Blurry game regulation, limited market scale, } \\
\text { high risks on policy, culture and economy }\end{array}$ \\
\hline
\end{tabular}

Theoretical Model on Developing Route of OEM Brand Internationalization. In the procedure of OEM-ODM-OBM-IBM, from an original scenario of low cost manufacturing and resembling, OEM enterprises can ultimately develop into those that possess capabilities of design, research and development and international brand operation. OEM brand internationalization values long term benefit of brands a lot. However, to build up an international brand, enterprises have to comprehensively figure out which markets should be the first target first.

Basing on the analysis on advantage and disadvantage factors of different countries markets, the author divides 3 types of market entrance models for studying the developing strategies that enterprises adopt to develop themselves from OEM, ODM, and OBM to IBM.

Table 3 Comparative Analysis on Different Market Entrance Models 


\begin{tabular}{|c|c|c|c|}
\hline Market Entrance & Route & Advantage Factors & Disadvantage Factors \\
\hline Hard $\rightarrow$ Easy & $\begin{array}{l}\text { From developed countries } \\
\text { to underdeveloped } \\
\text { countries }\end{array}$ & $\begin{array}{l}\text { Occupy competition commanding point } \\
\text { and make economic radiation; learn } \\
\text { advance experience from developed } \\
\text { countries. }\end{array}$ & $\begin{array}{l}\text { Huge input to initial brand } \\
\text { building; strong competitor; } \\
\text { high risk }\end{array}$ \\
\hline Medium Route & $\begin{array}{l}\text { Enter medium developed } \\
\text { countries markets before } \\
\text { entering underdeveloped } \\
\text { and developed countries }\end{array}$ & $\begin{array}{l}\text { Enrich market experience; medium } \\
\text { complexity; be able to expand to } \\
\text { developed and underdeveloped } \\
\text { markets. }\end{array}$ & Lack clear-cut route \\
\hline Easy $\rightarrow$ Hard & $\begin{array}{l}\text { From underdeveloped } \\
\text { countries to } \\
\text { developed countries }\end{array}$ & $\begin{array}{l}\text { Small steps to achieve big goals; easily } \\
\text { enter market to obtain primary } \\
\text { international experience; little input to } \\
\text { initial stage of brand building and quick } \\
\text { feedback. }\end{array}$ & $\begin{array}{l}\text { Hard to reverse brand } \\
\text { image; immature market } \\
\text { development; lack of } \\
\text { industrial regulations }\end{array}$ \\
\hline
\end{tabular}

Combing the above analysis, the author presents the theoretical model of this essay. 


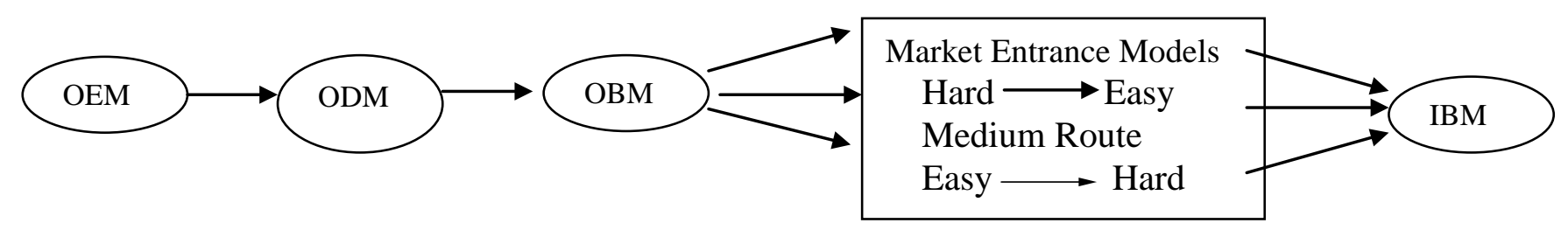

Fig. 2 Theoretical Model on Developing Route of OEM Brand Internationalization

\section{Research Method and Cases Selection}

Research Methods Selection. It explores not only OEM upgrade but also similarities and differences during carrying out brand internationalization. Currently, Lots of OEM enterprises in China are confronting with an upgrade dilemma. Some other enterprises gradually have accomplished their core competence building up and value chain rising. They also actively develop the international market. This essay studies 3 cases of OEM brand internationalization routes, sums up their stages of OEM-ODM, ODM-OBM, OBM-IBM and analyzes the strategies of structuring core technology and upgrade on every stages.

Target Cases Analysis. The selected 3 cases are, HTC, Galanz and TCL. HTC focused on OEM business in its early stage. Then it grabbed the tide of smart phone rising and named itself as HTC to exploit a self-owned brand market. Galanz Microwave oven is a powerful transnational OEM enterprise representative in the international market. TCL Group entered emerging countries markets in an OEM way. Afterwards it concentrated on capital operation and accumulated a huge awareness in both domestic and international markets. The 3 developing routes above present different attributes of stages.

\section{Stage Analysis on Developing Routes of OEM Enterprises}

The Analysis of the core competence and upgrading strategies from OEM to ODM. This upgrading requires the core competence of manufacturers upgrades from simple assembly to complete product R\&D and mature design capability. By breaking through technological barriers of key components, manufacturers stride forward towards the upper stream of the value chain.

1) Highlighting technological innovation and mastering the core competence

The persistent upgrading of organizational resources and corporate competence is beneficial to the sound operation of the enterprise and can create new competitive edges, thus guaranteeing sustainable development. At the start-up stage, HTC adopted traditional OEM mode which was popular among Taiwan electronic industry, manufacturing PDA, mobile phones and other digital products for such international brands as CPQ and HP. As for Galanz, it attached great importance to the combination of R\&D investment and the scale effect, mastering the core competence by learning technologies and keeping independent innovation. For example, it brought in the production line of the transformer which is a key component from the USA and Japan. And then Galanz researched, analyzed, imitated relevant technologies and then made improvement and innovations. For another example, to learn magnetron technology, Galanz enlarged investment and scaled up, unswervingly sticking to independent R\&D. As a result, it realized the scale effect. What's more, at early days, TCL also made great efforts to strengthen innovation, including establishing technological innovation committee, hiring pioneering experts as advanced consultants, increasing the R\&D investment from $7 \%$ of sales revenue to $10 \%$. All those efforts paid off-TCL maintained sustainable competitiveness.

2) Establishing sound cooperative relationship with other enterprises

According to Mao Yunshi and Wang Jiancheng(2006) establishing sound cooperative relationship with other enterprises benefits low-end manufacturers in "learning through practice" and "learning by using"[7]. Indeed, it was from the long-term cooperative treaty signed with Texas Instruments and Ericsson in 1998 that HTC obtained the supplementary assets like the resources of key components and R\&D technologies. Galanz, by allying with European large-scale household appliances 
enterprises, acquired more international orders in OEM and accumulated its capital. In addition, thanks to the close cooperation with Toshiba and benefited by the technology spillover effect, TCL gained core technologies in terms of colored TV R\&D and design.

3) Integrating global resources and realizing low-cost expansion through joint venture, merger, OEM and other capital operation modes

From the strategic cooperation with international giants like Microsoft and Google, HTC enriched the development of smart phones and marketing experience. After mastering core technologies, Galanz integrated upper stream suppliers through merger and joint venture with the help of its large-scale procurement. While for TCL, it enlarged the manufacturing scale of household appliances rapidly both at home and abroad, taking measures such as merger and low cost acquisition. It merged a number of colored TV enterprises, purchased German Schneider Colored TV, re-established TCL-Thomson Electronic with French Thomson. On the basis of integrating technology-oriented enterprises, TCL made global allocation of resources, decreased the cost for sustainable development and created its own advantages.

At the stage of OEM, enterprises can introduce core assembly lines, digest corresponding technologies, and then make innovations as well as building up independent core competence; develop partnership with cooperative enterprises; learn from other enterprises and accumulate experience; rapidly enlarge production lines and enrich developing routes through resources integration such as merger and OEM, make phased upgrading and move towards ODM gradually.

The Analysis of the core competence and upgrading strategies from ODM to OBM. This upgrading requires manufacturers possess the ability of complete products manufacturing and excellent products design, make innovations and differentiation the main routes of competition, move towards brand operation and realize the upgrading of functions.

1) Seizing opportunities in line with internal and external environments

In 2007 when Apple Inc issued the first generation of iPhone which was regarded as the beginning of smart phone era, the management of HTC held this opportunity and put huge efforts into the technological $R \& D$ of smart phones and independent brand operation. It reached strategic cooperation with Google and made effective responses to global challenges. As a result, HTC realized independent brand transition with Android system as the start. In 1998 when European countries imposed anti-dumping duties on SUMSUNG and LG microwave oven, Galanz successfully entered European microwave oven market which had been monopolized by Japanese and Korean enterprises for years. Likewise, against the backdrop of global IT structural adjustment, TCL widely participated in international technological cooperation and competition, optimize the allocation of resources and expand development space.

2) The awareness of brand innovation and entrepreneurship of the management

According to the case study of Rosen bloom (2002), the high-level managers can adjust the original strategic orientation to forge ahead development and revolution ${ }^{[8]}$. Disappointed by the low profit of OEM, Wang Xuehong, the founders of HTC resolutely decided to step onto the road of independent brand operation and gradually gave up OEM business. Thanks to the courage and wisdom of the above-mentioned founders, HTC integrated value chain operation and innovation thought, realizing its value upgrading.

3) Making strategic position of the brand and building up marketing capability

Combined with its own advantages, HTC formulated its own strategic position, namely, trying to be the terminal supplier which focused both on $\mathrm{R} \& \mathrm{D}$ and brand innovation. In terms of marketing ability, HTC adopted the method of "learning through practice" and set the small Hongkong brand Otek as an example, HTC accumulated the experience of brand operating. As for Galanz, it started from local brands, set different positions for various domestic and foreign markets and increased the proportion of exported products step by step. TCL attributed cooperate development to market expansion and technological progress.

From the processing and manufacturing in OEM to the products design in ODM and then to independent brand building in OBM, enterprises can accumulate technologies and experience, 
acquire large-scale production, design, innovation capabilities and other supplementary assets and realized primary upgrading of the value chain. Enterprises should seize the opportunities in internal and external environments, make brand innovation and strategic positions as well as building up the marketing network to create the largest additional value.

The Analysis of the core competence and upgrading strategies from OBM to IBM. He upgrading from OBM to brand internationalization requires manufacturers not only possess the ability of R\&D and brand marketing but also make brand operation globally so as to build up brand equity.

1) The upgrading strategy of HTC: launching market expansion by adopting "from hard to easy"

HTC chose the route of establishing brand in developed countries and then expanding to emerging markets. The strategic focus of HTC was to take American, Japanese and European major markets as the beginning. In 2008, HTC cooperated with Google and launched Mobile G1. Afterwards, it collaborated with British Telecom and shared the value of industry line with telecom operators. By doing so, HTC avoided industry competition and pried open the door of the European market. It was not until 2010 that HTC officially launched into mainland China and made close cooperation with Chinese mobile operators. This market access mode made HTC occupy the commanding height of competition, accumulate advanced management experience, learn technological knowledge from developed powerful brands and march into moderately developed and underdeveloped markets with irresistible force.

2) The upgrading strategy of Galanz: launching market expansion by adopting medium route

During the upgrading from OBM to IBM, Galanz adopted medium route, that is entering moderately developed markets at first and then accessing underdeveloped markets as well as developed markets. It forged ahead internationalization with the coexistence of OEM, ODM and OBM. In 1998, Galanz squeezed into European market when Korean and Japanese enterprises were forced out because of the imposed anti-dumping duties. Within only one year, its international market share topped 15\%; later, on the basis of its British, French and German markets, it joined hands with European large-scale household appliances and promoted products to underdeveloped regions and countries in Africa and Latin America. In this way, Galanz built up global distribution channels, enriched brand operating experience, and at last entered North American markets and increased global market occupying percentage.

3) The upgrading strategy of TCL: launching market expansion by adopting "from easy to hard"

During the upgrading from OBM to IBM, TCL adopted the mode of "from easy to hard". As early as 1999, it began to march into Vietnamese markets. Just within one and half year, TCL began to gain profits. In 2002, it successfully entered Middle East, Africa and Latin America. After realizing local management in emerging markets, building up mature marketing channels and obtaining sophisticated customer resources, TCL started to access developed markets, merging Schneider, Thomson and Arafat and other prestigious European enterprises. TCL adopted the tactic of multi-brands aiming at different marketing regions and consumption levels. TCL took advantage of the low entry threshold of underdeveloped markets and realized the effect of "low cost brand operation”.

\section{Conclusion}

During the process of brand internationalization, when upgrading from OEM to ODM, enterprises should focus on R\&D, develop core competitiveness and maintain sound relations with partners and realize scale economy in manufacturing; from ODM to OBM, enterprises should formulate long-term technological strategy and brand strategy and also be committed to increasing additional value; while from OBM to IBM, enterprises should build up global marketing network and set out differentiated market strategies, choose suitable market entry route in line with industry characteristics and owned resources to develop international brand. OEMs have the following routes to choose in terms of self-upgrading: First of all, it is of great importance to enhance independent R\&D and innovation awareness as well as knowledge digesting capacity. OEM enterprises can build up R\&D alliances, 
invest more to improve R\&D and design, on which basis, OEM enterprises can rapidly form organizing ability featuring technological learning and products innovation; secondly, by taking innovation and differentiation as the main channel of competition, OEM enterprises can build up its own marketing network and channels in line with external and internal environment and set brand strategic position to realize the upgrading of value chain; thirdly, the highest level of management should carry out brand internationalization positively, which can not only relieve domestic overwhelming competition but also create favorable conditions for sustainable development as well as larger development space.

\section{References}

[1] Amsden A H, Asia's next giant: South Korea and late industrialization, Oxford University Press, 1989.

[2] Prahalad C K, Hamel G, The core competence of the corporation, Harvard business review. 68(1990) 79-91.

[3] Humphrey J, Schmitz H, Governance and upgrading: linking industrial cluster and global value chain research, Brighton: Institute of Development Studies, 2000.

[4] Song Yonggao, Brand strategy and management, Zhejiang University Press,2003.

[5] Su Yong, International brand connotation and standard, Brand Strategy,2003

[6] Wei Fuxiang, Brand Internationalization: Mode Selection and Measurement, Journal of Tianjin University of Commerce.21(2001)

[7] Mao Yunshi, Wang Jiancheng, The Research of Independent Innovation Routes in Products Upgrading, Management World. 5(2006) 114-120.

[8] Chesbrough H, Rosenbloom R S. The role of the business model in capturing value from innovation: evidence from Xerox Corporation's technology spin-off companies,Industrial and corporate change, 11(2002): 529-555.

[9] Sun Xiaoqiang, Su Yong, The Routes of Brand Internationalization for Chinese Enterprises, Economic Management. 1(2007) 6-10.

[10] Hobday,M, Innovation in East Asia: The Challenge to Japan, Edward Elgar Publishing Limited, 1995.

[11] Liu Zhibiao, The Development of Manufacturing Industry in Chinese Coastal Regions: International OEM Modes and Innovation, Nankai Economic Research. 5 (2005) 37-44. 